\title{
Outside Director Equity Compensation And The Monitoring Of Management
}

\author{
Guy McClain, Auburn University, USA \& IESEG School of Management, Lille, France
}

\begin{abstract}
Using a sample of firms that are first time users of outside director equity compensation, I examine the effect of outsider director equity compensation on director monitoring by investigating firm performance and earnings management. My results, although lagged and not noticeable until year three, show that those firms that compensate outside directors with a higher percentage of equity compensation have higher stock performance, but lower accounting performance. These same firms also have lower discretionary accruals (i.e., less earnings management). These results suggest that outside directors do increase their monitoring by lowering discretionary accruals and thereby, lowering accounting earnings. In addition, this increased monitoring has a positive effect on stock performance. The results indicate that increased monitoring of accounting earnings results in lower discretionary accruals and thus lower, but more accurate earnings, and stock performance for the same period is not negatively impacted.
\end{abstract}

Keywords: Outside Director Equity Compensation; Firm Performance; Earnings Management; Discretionary Accruals

\section{INTRODUCTION}

C n July 2009 the Southern District of California approved a $\$ 55.95$ million settlement against six outside directors of Peregrine Systems for their role in the firm's failure to properly recognize revenue. This judgment brings the total amount paid in settlement of claims against the outside directors of Peregrine to $\$ 61.55$ million, one of the largest settlements ever solely on behalf of outside directors (LaCroix, 2009). Such lawsuits and judgments add fuel to the ongoing debate regarding the effectiveness of outside directors in the monitoring of management. While there are many factors that lead to, potentially, effective monitoring of management by outside directors, recent scrutiny has focused on the form of compensation (cash or equity). Therefore, the purpose of this study is to investigate the effect the form of compensation has on the monitoring of management. Specifically, this study focuses on first time adopters of an outside director equity compensation plan and examines firm performance (using both market and accounting measures) and discretionary accruals one, three and five years after plan implementation.

One reason firms use equity compensation is to provide incentives for the recipient to behave in ways that are in the best interest of shareholders. Agency theory predicts that equity compensation aligns outside directors' interest with those of shareholders (Elson, 1995; Jensen, 1989) by putting the outside directors' wealth at risk (Jensen, 1993). To the extent outside directors are self-interested, they can view board service (i.e., effort) as costly and the potential for shirking (i.e., rubber stamping) exists. This behavior could be exacerbated in firms with large investment and growth opportunities because the level of effort required to gather information and monitor management is sizable given the proprietary and specialized knowledge of management (Smith and Watts, 1992). Equity compensation, therefore, will alleviate these barriers to effective monitoring and improve an outside directors' incentive to maximize shareholder wealth (Maug, 1998).

The use of equity compensation, however, is not without concerns. While outside directors should make decisions with the goal of maximizing the long term wealth of owners (Sternberg, 2001), outside directors must not benefit at the expense of either shareholders or the corporation (Johnson et al., 2000). Equity compensation could 
be problematic since outside board members could set their compensation levels and performance targets (Dalton and Daily, 2001); focus on short term time horizons, if they are overly concerned with their present wealth instead of long term wealth effects (Daily and Dalton, 2002); and are in a position to directly influence stock price (Barrier, 2002). These concerns about directors' self-interest and potential wealth creation have been shown in the repricing of common stock (Arya and Sun 2004; Daily et al., 2002) and initial public offerings (Dalton et al., 2003).

Given the contrasting views on the efficacy of using equity in outside director compensation plans, I test the effect of equity compensation on two measures of outside director monitoring-firm performance and discretionary accruals. Equity compensation should reduce agency costs between outside directors and shareholders, enhancing firm performance. Cordeiro et al. (2007) find a positive relationship between equity compensation and stock returns, especially in firms with higher investment opportunities. I further investigate firm performance by testing accounting performance. Since accounting earnings do not include market wide changes to discount rates, earnings capture firm specific changes more under the directors' monitoring capacity. Fich and Shivdasani (2007) find a positive relationship between the existence of an equity plan and asset turnover, return on sales and return on assets.

Additionally, earnings management provides insight into monitoring of the financial reporting process-a specific duty of outside directors. Accruals are a necessary component in financial statements prepared in accordance with the standards set forth by the Financial Accounting Standards Board for public companies (those companies under the jurisdiction of the Securities and Exchange Commission.) Fundamentally, accruals are used to match expenses with the revenues they help create in a given accounting period ${ }^{1}$. Thus, some level of accruals is expected, and in and of itself, not reflective of management bias or a lack of director monitoring. Discretionary accruals, on the other hand, capture the amount of accruals that are managed. These discretionary accruals could be reflective of earnings management (either up or down) to meet a predetermined target. Regardless of the target (i.e., analyst forecast, performance measure, debt covenant), discretionary accruals decrease the representational faithfulness of financial reporting. Bédard et al. (2004) find that the ratio of outside director stock options that can be exercised in the short run relative to the total number of options held increases the probability that a firm will have discretionary accruals. Similarly, Boumosleh (2009) finds that the extent outside director option compensation is positively associated with total accruals.

I extend this research by examining the extent to which outside director equity compensation increases outside director monitoring as reflected in stock returns, return on assets, and discretionary accruals. I find that percentage of equity compensation, relative to total compensation, is positively (negatively) associated with stock returns (return on assets and discretionary accruals). These results are unique in that I am not testing the inclusion of equity, but rather the percentage of equity received in total compensation. Since all firms in my sample are receiving some level of equity, the results suggest that higher percentages of equity induce more monitoring. The results on stock performance are similar to Cordeiro et al. (2007), but extend that research by investigating accounting returns for a sample from a similar time period. The results on the discretionary accrual measures are opposite of Boumosleh (2009), but I do extend that research by investigating a more sophisticated measure of earnings management, discretionary accruals, rather than total accruals.

The remainder of the paper is organized as follows. Section 2 presents the literature review and hypotheses development. Section 3 describes the research design and data. Section 4 provides the empirical results and the paper is concluded in section 5 .

\section{PREVIOUS LITERATURE AND HYPOTHESES DEVELOPMENT}

The specter of corporate governance is that management will engage in self interested behaviors at the expense of shareholders (Jensen and Meckling, 1976). Therefore, boards of directors (among other governance features) are put in place on the authority of shareholders (Fama and Jensen, 1983a) to have ultimate responsibility

\footnotetext{
${ }^{1}$ For example, accounts receivables are presented on the balance sheet at their "net realizable value," the historical cost of the receivables less the estimated "allowance for doubtful accounts." The estimated "allowance for doubtful accounts" is the accrual that is reflected on the income statement as "bad debt expense."
} 
for decision making in the firm (Fama and Jensen, 1983b; Jensen 1983). The board of directors, therefore, is the mechanism by which management is monitored and ultimately disciplined (Fama, 1980; Jensen, 1983). Within this relationship between the outside directors and shareholders, however, there is an inherent conflict of interest — what Williamson (1984) refers to as secondary or cascading agency costs. The fundamental problem with this secondary agency relationship is that outside directors are not bonded with shareholders. That is, the outside directors are not tied, financially, to the results of the firm. Therefore, many scholars (for example Elson 1996; Jensen, 1983; Jensen, 1989) and professional organizations (see the National Association of Corporate Directors Blue Ribbon Report, 1995) have cited equity compensation as the solution to this bonding problem.

Equity compensation, in particular stock options, has a long and well-studied history in the executive compensation literature (for a thorough summary see Murphy, 1999). The reasoning behind the use of stock options in director compensation schemes is similar to executive compensation. Shareholders generally favor investment in risky projects, like $R \& D$, because the investment can potentially increase firm value, but the shareholders can diversify their risk by holding a portfolio of investments. On the other hand, management has incentives to under invest in R\&D. Management could avoid investments in R\&D because the investment has a high probability of failure (Finkelstein and Boyd, 1998) and the effects of the investment are long term. That is, the rewards of the R\&D investment could not be realized until well after the manger has left the firm (Rumlet, 1987). Outside directors, therefore, could be inclined to take a managerial approach to investment in R\&D (and other risky projects) since they serve at the pleasure of management (Davis and Thompson, 1994). Option compensation, thus, allows the outside director to share in firm gains from investment in risky projects in the same way as shareholders.

\subsection{Outside Director Compensation and Firm Performance}

Shareholders rely on outside directors to maximize shareholder wealth (Sternberg, 2001). Firm performance, in particular, is used to help assess wealth returns. One measure of firm performance is stock returns. Corderio, et al. (2007) find a positive relationship between the ratio of equity compensation and stock returns. One limitation of stock price measures of performance, however, is that all variation in stock price cannot be explained by managerial or director action. Previous research finds that variation in stock returns can be explained by both market wide shocks to discount rates and expected cash flows, an accounting measure (Campbell, 1990; Fama 1990). In fact, Fama (1976) shows that one-quarter to one-third of the variation in a firm's stock returns are explained by market wide fluctuations in discount rates.

Boumsoleh (2009) argues that director compensation contracts are becoming more similar to executive compensation contracts and, thus, provide similar incentives. Therefore, given that stock returns are assumed to be a noisy measure of performance as market wide fluctuations in the discount rate provide uncontrollable noise into the signal, outside directors can also be evaluated using accounting measures of performance. Accounting earnings provide information about a firm's current and future cash flow generating ability (Watts and Zimmerman, 1986). Since generally accepted accounting principles do not include the impact of market wide changes in discount rates on the computation of earnings, earnings are more sensitive to firm specific changes in value and reflect factors more under executive (in this case director) control (Lambert and Larcker, 1987; Sloan, 1993). Furthermore, since most firm debt is not publically traded, accounting earnings (with interest expense added back) are a beneficial indicator of changes in the value (stock plus debt) of the firm (Watts and Zimmerman, 1986). Therefore, the hypothesis in its alternative form is:

H1: Firm performance, as measured by stock returns and accounting earnings, is positively associated with outside director equity compensation.

\subsection{Outside Director Compensation and Earnings Management}

While stock options do put the recipient's wealth at risk, the literature on executive stock options suggest that incentives from stock options can be associated with earnings management through the manipulation of 
accruals $^{2}$. The literature on stock options and earnings management focuses on two similar, but distinct behaviors. The first focuses on earnings management around the issuance and exercise of stock options. The second investigates the relationship between compensation structure and earnings management.

Since stock prices react favorably to good news and negatively to bad news, executives could have incentives to manage the flow of information from their firm to shareholders. Aboody and Kasznik (2000), focusing on firms with scheduled option awards, find that executives who receive options before the earnings announcement are more likely to issue bad news and less likely to issue good news forecasts than are those executives who receive options after the earnings announcement date. Similarly, Chauvin and Shenoy (2001) find that stock returns are negative for the period preceding stock option awards. These results suggest that managers are able to inflate the value of options by timing the release of earnings news announcements. Yermack (1997) finds that managers influence the timing of awards rather than the timing of disclosures by showing positive abnormal stock returns following the option award date. Extending this notion, Baker et al. (2003) find that executives with high option compensation are associated with income decreasing accruals in periods prior to option award dates. In either situation, managers are able to extract wealth from shareholders by manipulating firm events.

Focusing on compensation structure, Gao and Shrieves (2002) find a negative (positive) relationship between cash (equity) and discretionary accruals. Similarly, Cheng and Warfield (2005) report greater earnings management (defined as using discretionary accruals to meet or beat analyst forecast) in firms that rely more heavily on equity compensation. Furthermore, Meek et al. (2007) find that the relationship between equity compensation and discretionary accruals can be moderated by firm size, growth and time period. Collectively, these studies provide evidence that equity compensation is positively associated with earnings management.

The quantity of evidence that investigates the effect of outside director equity compensation on earnings management is limited ${ }^{3}$. Earnings management, according to Healy and Wahlen (1999:368) occurs "when managers use judgment in financial reporting and structuring transactions to alter financial reports to either mislead some stakeholders about the underlying economic performance of the firm or to influence contractual outcomes that depend on reported accounting numbers." Accruals, in particular discretionary accruals, and earnings management are used synonymously in the literature (Kothari, 2001).

To date, only two studies have directly investigated outside director stock options and earnings management. Bédard et al. (2004) find that the ratio of stock options that can be exercised in the short run relative to the total of options and stock held by outside directors on the audit committee increases the probability that a firm will engage in discretionary accruals. Their findings suggest that stock options reduce the monitoring of earnings management to either increase earnings in the current period (positive discretionary accruals) or to accumulate reserves (negative discretionary accruals) to be used in subsequent years to increase earnings and, therefore, the value of the stock option. Boumosleh (2009) finds that the extent of equity compensation is positively associated with total accruals. This finding holds using the cumulative effect of equity compensation, implying that as outside directors receive more equity compensation over time they continue to manage earnings through accrual manipulation since their wealth (as represented by their increasing equity stake) is sensitive to changes in firm value. Both of these studies, in contrast to this study, take a cross-sectional approach to investigate outside director compensation structure and accruals.

There is a distinction between measuring total accruals and discretionary accruals. As stated previously, accruals are a necessary component of financial reporting. Therefore, research has put considerable effort into distinguishing between legitimate accruals (nondiscretionary) versus managed (discretionary) accruals. Prior

\footnotetext{
${ }^{2}$ Prior literature has also focused on option compensation and dividend policy. Option holders have incentives to avoid paying dividends since dividends reduce the value of the option and the option holder has no claim to the dividends (Merton, 1973). Lambert et al. (1989) find evidence that dividend payout ratios decrease relative to expected levels after the adoption of an executive stock option plan. Lewellen et al. (1987) find similar results.

${ }^{3}$ Previous research has shown that directors self-interestedly create wealth, at perhaps the expense of shareholders, during events like an initial public offering (Dalton et al., 2003), option repricing (Arya and Sun, 2004; Daily et al., 2002) and mergers and acquisitions (Certo et al., 2008). They, however, do not test earnings management through the manipulation of accruals.
} 
research has shown earnings management as measured by discretionary accruals in situations as diverse as executive compensation contracts (Healy, 1985), litigation awards (Hall and Stammerjohan, 1997), and regulatory hearings (Key 1997). ${ }^{4}$ Therefore, using a discretionary accrual model helps capture earnings management, the accruals that truly are at management's discretion and not effectively monitored by outside directors. The second hypothesis in alternative form is as follows:

H2: Discretionary accruals are positively associated with outside director equity compensation.

\section{DATA AND RESEARCH METHODOLOGY}

\subsection{Empirical Specification}

The test variable in this study is director equity mix (DEM), the dollar value of equity compensation divided by the dollar value of total compensation. Total compensation is the aggregate of cash compensation (the total dollar amount of board retainers plus the meeting fee times the number of full board meetings) and equity compensation. Equity compensation is valued as the number of options awarded times the per-option value derived using the Black-Scholes (1973) option-pricing formula. Similar to prior studies (e.g., Certo et al., 2008) I assume the options are awarded at the money and the time to maturity is ten years.

\subsubsection{Outside Director Equity Compensation and Firm Performance}

The first hypothesis of this paper is whether director equity mix (DEM) is positively associated with measures of firm performance. I distinguish between stock returns and accounting returns in my empirical models. For both measures of performance I calculate the one-year, three- and five-year industry adjusted average. Stock based performance, stock returns (RTN), is measured as average monthly return of a firm's stock over the period of interest minus the firm's two-digit SIC average monthly return divided by the standard deviation of the industry average monthly returns over the desired time period.

Return on assets (ROA) is used to measure accounting returns. Although prior literature has used return on equity as an accounting proxy (Ryan and Wiggins, 2004), industry adjusted return on assets is used in this study. Unlike return on equity, return on assets captures how assets are efficiently used, more fully capturing events monitored by the outside directors. It is calculated as the difference between a firm's return on assets (calculated as income from continuing operations before interest expense and taxes divided by average total assets) and the firm's two-digit SIC average return on assets, divided by the standard deviation of the average industry return on assets for the desired time period.

The regressions on firm performance also include variables for the firm's corporate governance structure and agency cost characteristics. Board size (BDS) is included to control for the negative relationship between board size and firm valuation (Yermack, 1996). The number of board meetings (BDM) is used as a control because firm performance increases with an increase in the number of board meetings (Vafeas, 1999). Board independence (OUT) is measured as the percentage of outside directors on the board, since board independence enhances firm value (Hermalin and Weisbach, 1991). Management entrenchment is captured by insider ownership (INO), and is the percentage of common shares owned by executive management (Hermalin and Weisbach, 1991). Size (SZE) is the natural log of total assets. The percentage of CEO cash compensation (CCC) is used to capture potential incentive effects of the CEO compensation mix. The more cash in a CEO's compensation scheme the less likely they would manage towards market measures of performance.

I use an ordinary least squares regression model to test the relationship between outside director equity compensation and firm performance. Specifically, I run regressions of firm performance (stock returns and accounting returns) over the proportion of equity in total compensation. Hypothesis one, that outside director equity compensation increases the monitoring activities of outside directors, thereby reducing the agency costs between outside directors and shareholders, predicts a positive relationship between the mix of equity compensation and firm

\footnotetext{
${ }^{4}$ See Dechow and Schrand (2004) for a thorough review of all earnings management literature. 
performance. In the regression firm performance is defined as either stock returns or return on assets ${ }^{5}$. For each performance measure, I calculate the one year return and the three- and five-year average return. Control variables are also their values at one, three and five years after the plan adoption. The regression equation is as follows:

$\mathrm{DEP}_{\mathrm{k}, \mathrm{t}}=\beta_{\mathrm{o}}+\beta_{1} \mathrm{DEM}_{\mathrm{k}, \mathrm{t}}+\beta_{2} \mathrm{BDS}_{\mathrm{k}, \mathrm{t}}+\beta_{3} \mathrm{BDM}_{\mathrm{k}, \mathrm{t}}+\beta_{4} \mathrm{OUT}_{\mathrm{k}, \mathrm{t}}+\beta_{5} \mathrm{INO}_{\mathrm{k}, \mathrm{t}}+\beta_{6} \mathrm{SZE}_{\mathrm{k}, \mathrm{t}}+\beta_{7} \mathrm{CCC}_{\mathrm{k}, \mathrm{t}}+$ error $_{\mathrm{k}, \mathrm{t}}$

Where $\mathrm{k}$ indicates the firm and $\mathrm{t}$ indicates the year;

$\mathrm{DEP}_{\mathrm{k}, \mathrm{t}}=\quad$ one of two variables: stock returns $(\mathrm{RTN})$ measured as average monthly return of a firm's stock over the period of interest minus the firm's two-digit SIC average monthly return divided by the standard deviation of the industry average monthly returns over the desired time period; or return on assets (ROA) calculated as the difference between a firm's return on assets (calculated as income from continuing operations before interest expense and taxes divided by average total assets) and the firm's two-digit SIC average return on assets, divided by the standard deviation of the average industry return on assets for the desired time period.

$\mathrm{DEM}_{\mathrm{k}, \mathrm{t}}=$ director equity mix, calculated as the dollar value of equity compensation divided by the dollar value of total compensation

$\mathrm{BDS}_{\mathrm{k}, \mathrm{t}}=$ board size, calculated as the total number of board members

$\mathrm{BDM}_{\mathrm{k}, \mathrm{t}}=$ board meetings, calculated as the total number of full board meetings during the year

$\mathrm{OUT}_{\mathrm{k}, \mathrm{t}}=$ percentage of outside board members, calculated as the number of outside board members divided by the total number of board members

$\mathrm{INO}_{\mathrm{k}, \mathrm{t},}=$ insider ownership, calculated as the percentage of common shares owned by executive management

$\mathrm{SZE}_{\mathrm{k}, \mathrm{t}}=\quad$ size, calculated as the natural log of total assets

$\mathrm{CCC}_{\mathrm{k}, \mathrm{t}}=\mathrm{CEO}$ cash compensation, calculated as the total dollar value of CEO cash compensation divided by total compensation

\subsubsection{Outside Director Compensation and Discretionary Accruals}

The second hypothesis tested in this study is whether director equity mix (DEM) is positively associated with discretionary accruals (DA). First, however, total accruals must be calculated. I calculate total accruals using a cash-flow model as used in Hribar and Collins (2002) because of measurement error that potentially exists in using a balance sheet approach. Hribar and Collins (2002) find that the articulation between changes in balance sheet accounts (working capital) and income statement accounts (accrued revenues and expenses) breaks down when nonoperating events are present (mergers and acquisitions, divestitures and foreign translations). Thus, total accruals are calculated as follows:

Total Accruals $=($ Earnings before income taxes - cash flows $) /$ lag assets

Where earnings is income before extraordinary items and discontinued operations, cash flow is net operating cash flow, and assets are the total assets at the beginning of the year.

Discretionary accruals are then estimated using the cross-sectional Jones (1991) model with piecewise modifications, as suggested by Ball and Shivakumar (2006). The Jones (1991) model totals accruals as a function of the change in revenues and the level of property, plant and equipment $\left(\beta_{1}\right.$ and $\beta_{2}$ in Equation 2, below). The

\footnotetext{
${ }^{5}$ The regression was re-estimated with market-to-book and earnings per share as measures of firm performance. The results were consistent across all years tested. 
adjustments recommended by Ball and Shivakumar (2006) control for current period performance and timing of gain and loss recognition ( $\beta_{3}, \beta_{4}$ and $\beta_{5}$ in Equation 2, below). Model specification is improved with the adjustments as shown in tests conducted by Ball and Shivakumar (2006). The model is specified as follows:

Total accruals $=\beta_{0}+\beta_{1}$ Change in revenue $+\beta_{2}$ Property, plant and equipment $+\beta_{3}$ Cash flows $+\beta_{4}$ Negative cash flows $+\beta_{5}$ (Cash flows $X$ Negative cash flows)+error

Where the change in revenue is the one year change in net sales, property, plant and equipment is the gross property, plant and equipment, cash flows is the net operating cash flows, and negative cash flows is a dummy variable, 1 if the operating cash flow is less than zero. All variables except negative cash flows are scaled by lagged total assets. Equation (2) is estimated cross-sectionally for each two-digit SIC grouping and year combination. Prediction errors from the OLS parameter estimates in Equation (2) represent the firm's discretionary accruals (DA).

The regressions on discretionary accruals also control for leverage, market-to-book, cash flows and outside directors. Previous studies (e.g., Becker et al., 1998; Frankel et al., 2002; Menon and Williams, 2004) have shown a positive relationship between discretionary accruals and leverage and market-to-book. Leverage (LVG) is the sum of long term debt and the portion of long term debt in current liabilities scaled by total assets. While debt does serve as an external monitor of management, those companies near debt constraints could be motivated to manage earnings (DeFond and Jiambalvo, 1994). Market-to-book (MTB) is market capitalization plus the book value of long term debt scaled by total assets. It is used to capture the growth opportunities of firms, perhaps allowing managers more discretion in making accounting judgments. Cash flows (CFL), operating cash flows scaled by total assets, is included because they have been shown to vary inversely with discretionary accruals (Dechow et al., 1995). Percentage of outsiders (OUT) on the board is used to capture board independence as more independent boards are more likely to monitor management.

I test hypothesis two, the effect of director equity mix (DEM) on discretionary accruals, also on measures one, three and five years after plan adoption. Again, control variables are their values one, three, and five years after plan adoption. A positive relationship is predicted indicating that equity compensation is associated with higher accruals indicating lax monitoring creating the potential for earnings manipulation. The equation for this regression is as follows:

$\mathrm{DA}_{\mathrm{k}, \mathrm{t}}=\beta_{0+} \beta_{1} \mathrm{DEM}_{\mathrm{k}, \mathrm{t}}+\beta_{2} \mathrm{CFL}_{\mathrm{k}, \mathrm{t}}+\beta_{3} \mathrm{LVG}_{\mathrm{k}, \mathrm{t}}+\beta_{4} \mathrm{MTB}_{\mathrm{k}, \mathrm{t}}+\beta_{5} \mathrm{OUT}_{\mathrm{k}, \mathrm{t}}+$ error

Where $\mathrm{k}$ indicates the firm and $\mathrm{t}$ indicates the year;

$\mathrm{DEM}_{\mathrm{k}, \mathrm{t}}=$ director equity mix, calculated as the dollar value of equity compensation divided by the dollar value of total compensation

$\mathrm{CFL}_{\mathrm{k}, \mathrm{t}}=$ cash flows, calculated as operating cash flows scaled by total assets

$\mathrm{LVG}_{\mathrm{k}, \mathrm{t}}=$ leverage, calculated as the sum of long term debt and the portion of long term debt in current liabilities scaled by total assets

$\mathrm{MTB}_{\mathrm{k}, \mathrm{t}}=$ market-to-book, calculated as market capitalization plus the book value of long term debt scaled by total assets

$\mathrm{OUT}_{\mathrm{k}, \mathrm{t}}=$ percentage of outside board members, calculated as the number of outside board members divided by the total number of board members

\subsection{Data and Sample}

To test the hypotheses in the paper, I use a sample of firms that are first time adopters of an outside director compensation plan that includes equity from the period 1997-2000. I use first time adopters because it provides an opportunity to measure director behavior around the time the equity compensation plan is adopted. This sample of 
firms allows me to investigate the initial effect equity compensation has on outside director monitoring. This method is in contrast to studies that more broadly investigate the cross-sectional relationship between director compensation structure and performance/accruals. I chose the period (1997-2000) for several reasons. First, the National Association of Corporate Directors issued its Blue Ribbon Report in 1995 that recommended the use of equity compensation. Also, in 1996 the SEC relaxed the provisions of Rule 16b-3 allowing companies more discretion to issue stock options. Thus, by 1997 firms that had not used equity compensation (because, perhaps, they did not have an appealing investment opportunity set, Cordeiro et al. 2007; Fich and Shivdasani, 2005; Linn and Park, 2005) could be feeling pressure to do so since it was not only recommended but easier to do. Second, the period is before the Enron scandal and the increased level of scrutiny from all parties (e.g., auditors, regulators, Congress) involved in the financial reporting process. Thus, director performance is more likely to be the result of compensation changes than other factors.

To create a sample of first time adopters I queried the Standard \& Poor's ExecuComp database for all firms that had outside directors who received zero equity compensation in 1997, 1998, 1999, and 2000. The initial sample included 734 firms, of those 415 financial services or utility firms were excluded because they operate in an industry in which government regulation acts as an additional layer of monitoring. Next, individual queries on each of the remaining 319 firms were performed to identify the first year outside directors received either stock grants or stock options. One hundred eighty seven firms were eliminated because equity compensation has been used in previous years. Of the 132 remaining firms, 16 firms were eliminated because financial information was not available and 27 were eliminated because they did not have 5 years of additional financial information beyond the plan adoption date due to either mergers/ acquisitions (23) or delisting of trading securities (4).

Thus, there is a final sample of 89 firms used to test hypothesis one related to firm performance. Hypothesis two, related to discretionary accruals, has a final sample of 81 , as 8 firms were eliminated due to incomplete information. Once a firm was identified as feasible and plan adoption date identified, financial variables were obtained from Compustat while market related data were obtained from CRSP. Board of director variables such as compensation and composition are collected from firm proxy statements filed on the Securities and Exchange Commission's EDGAR database. Table 1 presents the distribution of the sample firms by industry and year.

Table 1

Distribution of sample firms by year of equity plan adoption and Standard Industry Code (SIC)

\begin{tabular}{lcc}
\hline \multicolumn{2}{c}{ Panel A: The distribution by year of equity plan adoption } & \\
\hline \multicolumn{2}{c}{ Year of equity plan adoption } & Number of firms in sample \\
\hline 1997 & & 9 \\
1998 & & 25 \\
1999 & & 29 \\
2000 & Total & 89 \\
\hline & & Firms in sample \\
\hline Panel B: The distribution by SIC & Industry Description & 6 \\
\hline SIC & Primary & 16 \\
\hline 1 & Manufacturing- nondurables & 27 \\
3 & Manufacturing- durables & 6 \\
4 & Transportation & 12 \\
5 & Wholesalers and Retailers & 22 \\
7 & Business Services & 89 \\
\hline
\end{tabular}

\section{RESULTS}

\subsection{Descriptive Statistics}

Table 2 contains summary statistics for selected variables. Panel A reports descriptive statistics for the variables used to test hypothesis one related to firm performance. The average firm had total assets of $\$ 2.9$ million. The average board had 9 members, $62 \%$ being outsiders, and met 6.6 times a year. Equity, on average, comprised 
$55 \%$ of the directors' compensation and $43 \%$ of the CEO's compensation. Additionally, insiders owned $13.3 \%$ of outstanding stock. It is clear from Panel A that equity is a significant portion of the directors' compensation.

Panel B of Table 2 provides descriptive statistics for the variables used to test hypothesis two related to discretionary accruals. Even though sample size does decrease from hypothesis one to hypothesis two, common variables like director equity mix and the percentage of outsiders on the board do not significantly change from Panel A. Operating cash flows, on average, were $11 \%$ of total assets. The average firm had a market-to-book ratio of 2.47 and used leverage about $50 \%$ of the time. The high amount of leverage might explain why, on average, these firms might be perceived as late adopters of an outside director equity plan.

Table 2

Descriptive statistics of all variables at the time of equity plan adoption

\begin{tabular}{|c|c|c|c|c|c|}
\hline \multicolumn{6}{|c|}{ Panel A: Sample to test firm performance, $(89$ observations) } \\
\hline Variables & Mean & Median & Maximum & Minimum & Standard Deviation \\
\hline RTN & .01 & .01 & .23 & -.09 & .05 \\
\hline ROA & .06 & .06 & .22 & -.30 & .06 \\
\hline DEM & .55 & .54 & 1.00 & .06 & .28 \\
\hline BDS & 9.10 & 9.00 & 16.00 & 4.00 & 2.75 \\
\hline BDM & 6.67 & 6.00 & 18.00 & 2.00 & 2.86 \\
\hline OUT & .62 & .64 & .92 & .25 & .16 \\
\hline INO & .13 & .09 & .72 & .01 & .13 \\
\hline SZE & $2,926.830$ & $1,122.410$ & $30,891.700$ & 50.840 & $4,638.310$ \\
\hline $\mathrm{CCC}$ & .57 & .53 & 1.00 & .00 & .28 \\
\hline \multicolumn{6}{|c|}{ Panel B: Sample to test discretionary accruals, (81 observations) } \\
\hline Variables & Mean & Median & Maximum & Minimum & Standard Deviation \\
\hline $\mathrm{DA}$ & .03 & .02 & .27 & -.18 & .06 \\
\hline DEM & .54 & .49 & 1.00 & .06 & .28 \\
\hline $\mathrm{CFL}$ & .12 & .11 & .43 & -.07 & .08 \\
\hline LVG & .50 & .53 & .84 & .14 & .17 \\
\hline MTB & 2.47 & 1.71 & 10.81 & .38 & 2.16 \\
\hline OUT & .62 & .63 & .92 & .25 & .16 \\
\hline
\end{tabular}

Variable definitions

RTN is stock returns, measured as average monthly return of a firm's stock over the period of interest minus the firm's two-digit SIC average monthly return divided by the standard deviation of the industry average monthly returns over the desired time period

ROA is return on assets, calculated as the difference between a firm's return on assets (calculated as income from continuing operations before interest expense and taxes divided by average total assets) and the firm's two-digit SIC average return on assets, divided by the standard deviation of the average industry return on assets for the desired time period.

DEM is director equity mix, calculated as the dollar value of equity compensation divided by the dollar value of total compensation

BDS is board size, calculated as the total number of board members

BDM is board meetings, calculated as the total number of full board meetings during the year

OUT is the percentage of outside board members, calculated as the number of outside board members divided by the total number of board members

INO is insider ownership, calculated as the percentage of common shares owned by executive management

SZE is firm size, calculated as the natural log of total assets

CCC is CEO cash compensation, calculated as the total dollar value of CEO cash compensation divided by total compensation

DA is discretionary accruals, calculated using the cross-sectional Jones (1991) model with piecewise modifications, as suggested by Ball and Shivakumar (2006).

CFL is cash flows, calculated as operating cash flows scaled by total assets

LVG is leverage, calculated as the sum of long term debt and the portion of long term in current liabilities scaled by total assets

MTB is market-to-book, calculated as market capitalization plus the book value of long term debt scaled by total assets

\subsection{Univariate Analyses}

Tables 3 and 4 provide the correlation matrices for the independent variables used to test hypothesis one, related to firm performance and hypothesis two, related to discretionary accruals. The variables shown are for the period one-year after plan adoption, except for director equity mix, the equity mix at the time of adoption. 
Performance variables and discretionary accruals are also included for three and five years after plan adoption. Generally, the correlations between the independent variables do not suggest that multicollinearity is a problem. The correlation between director equity mix and stock returns is positive for all years presented. This result is consistent with the prediction that equity compensation motivates outside directors to increase their monitoring activities to maximize shareholder value. Contrary to my argument, however, is the negative correlation between director equity mix and return on assets, especially in years three and five. Additionally, the negative correlation between director equity mix and discretionary accruals is contrary to my prediction suggesting that equity compensation does provide motivation to aggressively monitor management.

Table 3

Correlation matrix for variables used to test firm performance (89 observations)

\begin{tabular}{|c|c|c|c|c|c|c|}
\hline & $\begin{array}{l}\text { RTN } \\
\text { year } 1\end{array}$ & $\begin{array}{l}\text { RTN } \\
\text { year } 3\end{array}$ & $\begin{array}{l}\text { RTN } \\
\text { year } 5\end{array}$ & $\begin{array}{l}\text { ROA } \\
\text { year } 1\end{array}$ & $\begin{array}{l}\text { ROA } \\
\text { year } 3\end{array}$ & $\begin{array}{l}\text { ROA } \\
\text { year } 5\end{array}$ \\
\hline RTN year 1 & 1.00 & & & & & \\
\hline RTN year 3 & $.91 * * *$ & 1.00 & & & & \\
\hline RTN year 5 & $.84 * * *$ & $.98 * * *$ & 1.00 & & & \\
\hline ROA year 1 & .14 & .15 & .09 & 1.00 & & \\
\hline ROA year 3 & .06 & .14 & .12 & $.82 * * *$ & 1.00 & \\
\hline ROA year 5 & -.17 & $-.27 *$ & $-.27 *$ & $.45^{* * *}$ & $.63 * * *$ & 1.00 \\
\hline DEM & $.26^{*}$ & $.33 * *$ & $.34 * * *$ & -.03 & -.17 & $-.28 * * *$ \\
\hline BDS & $-.21 * *$ & $-.32 * *$ & $-.37 * * *$ & .01 & .01 & .10 \\
\hline BDM & .16 & $.19 \dagger$ & $.18 \dagger$ & -.11 & $-.19 \dagger$ & $-.40 * *$ \\
\hline OUT & $-.20 \dagger$ & $-.19 \dagger$ & $-.18 \dagger$ & .08 & .02 & .01 \\
\hline INO & -.10 & -.12 & -.15 & .06 & -.05 & -.01 \\
\hline SZE & .17 & .10 & .06 & $.25 *$ & $.36 * * *$ & $.29 * *$ \\
\hline \multirow[t]{2}{*}{$\mathrm{CCC}$} & .07 & $.18 \dagger^{*}$ & $.20 \dagger$ & .13 & .10 & -.03 \\
\hline & DEM & BDS & BDM & OUT & INO & SZE \\
\hline DEM & $1.00 * * *$ & & & & & \\
\hline BDS & $-.46^{* * * *}$ & 1.00 & & & & \\
\hline BDM & $0.04 * * *$ & -.06 & 1.00 & & & \\
\hline OUT & $-.17 * * *$ & .11 & -.01 & 1.00 & & \\
\hline INO & $0.08 * * *$ & -.03 & -.03 & -.11 & 1.00 & \\
\hline SZE & $-.12 * * *$ & $.37 * * *$ & .03 & -.06 & $-.25 * * * *$ & 1.00 \\
\hline $\mathrm{CCCC}$ & $0.09 * * *$ & $-.28 * *$ & .05 & -.12 & $.19 \dagger$ & $-.28 * * *$ \\
\hline
\end{tabular}

$\dagger$ denotes significance at $\mathrm{p}<.10$

$*$ denotes significance at $\mathrm{p}<.05$

$* *$ denotes significance at $\mathrm{p}<.01$

$* * *$ denotes significance at $\mathrm{p}<.001$

Table 4

Correlation matrix for variables used to test discretionary accruals (81 observations)

\begin{tabular}{|c|c|c|c|c|c|c|c|c|}
\hline & $\begin{array}{l}\text { DA } \\
\text { year } 1 \\
\end{array}$ & $\begin{array}{l}\text { DA } \\
\text { year } 3\end{array}$ & $\begin{array}{l}\text { DA } \\
\text { year } 5\end{array}$ & DEM & CFL & LVG & MYB & OUT \\
\hline DA year 1 & 1.00 & & & & & & & \\
\hline DA year 3 & $.21 \dagger$ & 1.00 & & & & & & \\
\hline DA year 5 & .17 & $.56 * * *$ & 1.00 & & & & & \\
\hline DEM & .05 & -.15 & $-.24 * * *$ & 1.00 & & & & \\
\hline CFL & .07 & .01 & $-.24 * * *$ & 0.13 & 1.00 & & & \\
\hline LVG & -.09 & -.01 & -.08 & $-.36 * * *$ & $-.44 * * *$ & 1.00 & & \\
\hline MTB & .16 & .03 & .10 & $.45 * * *$ & $0.35 * * *$ & $-.37 * * *$ & $1.00 * * *$ & \\
\hline OUT & -.01 & -.14 & -.08 & -.13 & 0.13 & 0.13 & -.12 & 1.00 \\
\hline $\begin{array}{l}\dagger \text { †denotes si } \\
* \text { denotes s } \\
* * \text { denotes } \\
* * * \text { denote }\end{array}$ & $\begin{array}{l}.10 \\
.05 \\
0<.01 \\
p<.001\end{array}$ & & & & & & & \\
\hline
\end{tabular}




\subsection{Multivariate Analyses}

Panel A of Table 5 presents the results of using stock returns as the dependent variable, while Panel B shows the results of using return on assets. In both panels column (1) presents the one-year return, column (2) presents the three-year average and column (3) presents the five-year average. Hypothesis one predicts a positive relationship between the mix of equity compensation and stock returns. Consistent with earlier work (Cordeiro et al., 2007) equity compensation is positively related to stock returns. However, as Panel A, column (1) indicates that positive relationship is not evident the first year after equity compensation, but rather in year three. Furthermore, as Panel B reports, the significant relationship carries over to year five. Panel B, indicates a similar lagged trend with the effect of equity compensation not noticeable until years three and five when using return on assets as the dependent variable. The results, however, indicate a negative relationship between director equity mix and return on assets. Thus, the results only partially support hypothesis one, since the relationship between equity compensation and accounting earnings is negative.

Table 6 presents the results of the regression for hypothesis two regarding discretionary accruals. Similar to the results in Table 5, the effect of the equity compensation is lagged. Column (1) indicates no relationship between equity compensation and discretionary accruals, while columns (2) and (3) show a significant and negative relationship between equity and discretionary accruals. The results are contrary to hypothesis two, suggesting that more equity compensation provides incentives for directors to aggressively monitor management by decreasing unnecessary, or discretionary accruals.

Table 5

Test for the effects of equity compensation on firm performance as measured by stock returns and return on assets ( 89 observations)

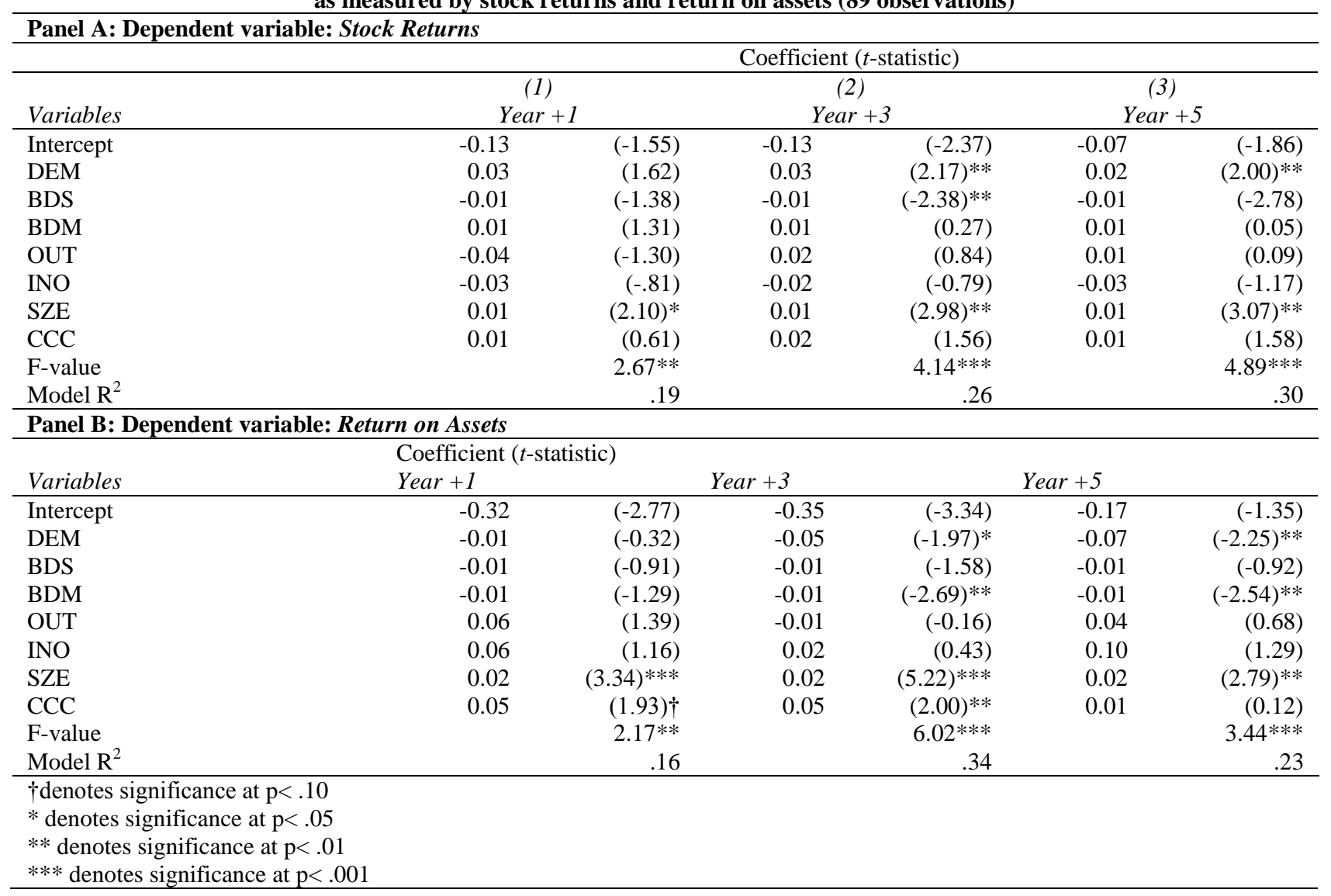




\section{CONCLUSION}

This research investigates the effect of outside director equity compensation on director monitoring, by examining its relationship with firm performance and earnings management. While previous research suggests that firm performance increases as equity compensation increases (Cordeiro et al., 2007), I find that to be only partially correct. Investigating both stock returns and accounting earnings measures, I find that outside director equity compensation is positively (negatively) associated with stock returns (accounting earnings), which is partially consistent with the findings of (Cordeiro et al., (2007). Further, previous research suggests that outside director equity compensation provides incentives for outside directors to compromise their monitoring responsibility as indicated by a strong positive association with total accruals (Boumosleh, 2009). Contrary to those results, I find that outside director compensation is negatively associated with discretionary accruals.

Table 6

Test for the effects of equity compensation on discretionary accruals (81 observations)

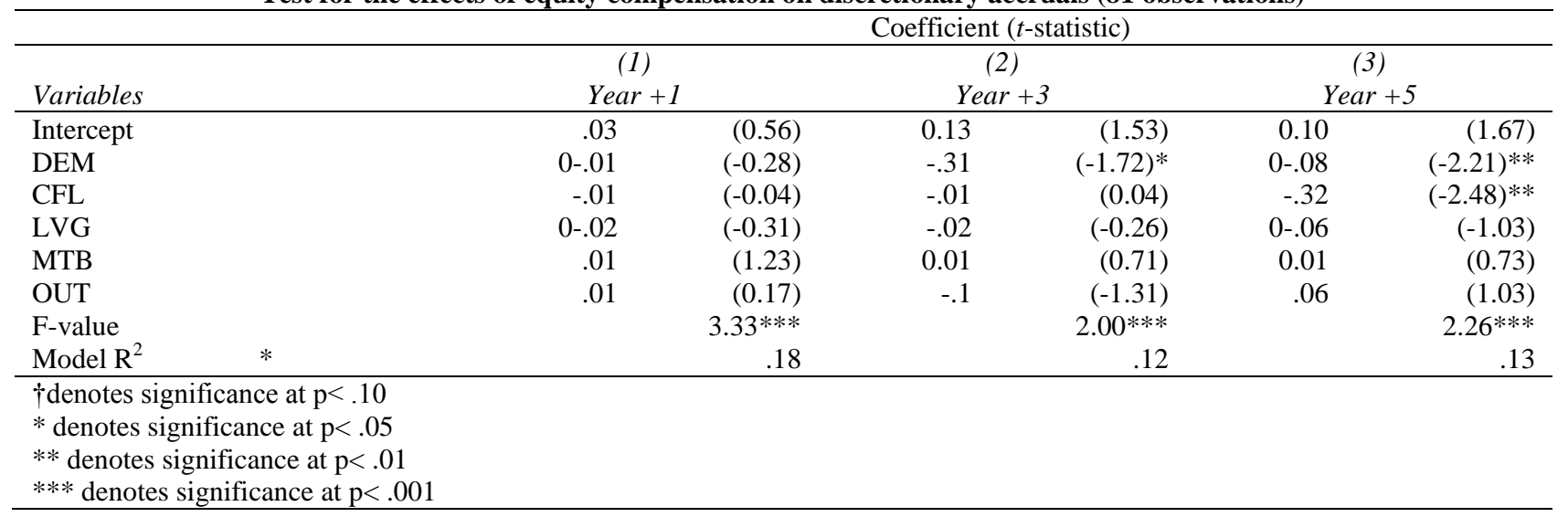

In isolation, my firm performance results suggest that outside directors could be acting self-interestingly by engaging in behavior that increases stock performance to the detriment of accounting earnings. However, when taking into account the relationship with discretionary accruals, a different interpretation unfolds. I would argue that outside directors with a higher percentage of equity compensation monitor more by decreasing abnormal accruals, thereby reducing accounting earnings and making them more accurate. The positive association with stock performance suggests that equity compensation is also increasing the monitoring of firm-level investment decisions.

This research contributes to the literature in a number of ways. First, it adds additional evidence on the debate surrounding outside director equity compensation. Prior studies have individually investigated firm performance (Cordeiro et al., 2007) and earnings management (Boumosleh, 2009) and show contrasting results. My study adds another piece of evidence on the monitoring effects of outside director equity by investigating performance and earnings management at the same time. Second, this study explores a unique research setting. I argue that many of the variables used in governance studies like board independence, compensation, performance and other observed outcomes are endogenously determined over time. Firm performance may be both a result of the test variables (outside director equity compensation and agency costs) and a factor that influences subsequent changes in those variables. To the extent subsequent compensation anchors on initial negotiation, models that do not take the initial anchoring into account may confound interpretation of resulting coefficients. By using a sample of firms in the initial year of an outside director equity compensation plan, the study is better able to determine if the test variables reflect performance or vice versa, which begins to get to the root of the debate regarding outside director compensation.

My study is subject to several limitations. First, due to small sample size any generalization of these results to other firms should proceed with caution. Also, the sample is from a time period prior to Sarbanes-Oxley. Since the passage of Sarbanes-Oxley the demands, compensation, qualifications, and time commitments required by outside directors have changed dramatically. While these results do shed light on the fundamental differences 
among compensation components, director attitudes and responsibilities may have changed in such a way as to override these findings. Third, the data is from a single country which does not allow me to generalize my findings to other markets.

I have identified some useful future research ideas. In my results the effects of equity compensation are not noticeable until three and five years after the plan adoption. Therefore, future research could explain what factors speed up or slow down the implementation of governance reforms and how to make their effect more immediate. In addition, the results are contrary to research by Boumosleh (2009) that indicates equity compensation provided monitoring disincentives for outside directors, particular in the manipulation of accruals. One reason, perhaps, for the contrasting results would be my sample. Since I use a sample of first time adopters, the long term effect of equity compensation is not tested. It could be that governance reforms initially motivate directors to monitor more aggressively but fade over time. Another potential area for research could investigate the stickiness of new governance mechanisms. Related to this would be to investigate what causes outside directors to relax their integrity and the consequences of that behavior. For example, Bøhren (1998) asked at what point is an agent indifferent to the dishonest use of private information and, therefore, derives no discomfort from using private information in a dishonest way? Thus, more work is needed to understand the intersection between motivation and disincentive.

\section{AUTHOR INFORMATION}

Guy McClain is an assistant professor of accounting at Auburn University and an Affiliated Professor at the IESEG School of Management in Lille, France. His main research interests are corporate governance, compensation and financial reporting/disclosure. E-mail: gmm0003@auburn.edu

\section{REFERENCES}

1. Aboody, D. \& Kasznik, R. (2000). CEO Stock Option Awards and the Timing of Corporate Voluntary Disclosures. Journal of Accounting and Economics, 29 (1) 73-100.

2. Arya, A. \& Sun, H. (2004). Stock Option Repricing: Heads I Win, Tails You Lose. Journal of Business Ethics, 50 (4) 297-312.

3. Baker, T., Collins, D. \& Reitenga, A. (2003). Stock Option Compensation and Earnings Management. Journal of Accounting, Auditing and Finance, 18 (4) 557-582.

4. Ball, R. \& Shivakumar, L. (2006). The Role of Accruals in Asymmetrically Timely Gain and Loss Recognition. Journal of Accounting Research, 44(2) 207-242.

5. $\quad$ Barrier, M. (2002). The Compensation Balance, Internal Auditor, 59 (3) 42-47.

6. Becker, C., DeFond, M., Jiambalvo, J. \& Subramanyam, K. (1998). The Effect of Audit Quality on Earnings Management. Contemporary Accounting Research, 15 (1) 1-24.

7. Bédard, J., Chtourou, S. \& Courteau, L. (2004). The Effect of Audit Committee Expertise, Independence, and Activity on Aggressive Earnings Management. Auditing: A Journal of Practice \& Theory, 23 (2) 1335.

8. Black, F. \& Scholes, M. (1973). The Pricing of Options and Corporate Liabilities. Journal of Political Economy, 81 (3) 637-654.

9. Bøhren, Ø. (1998). The Agent's Ethics in the Principal-Agent Model. Journal of Business Ethics, 17 (7) 745-755.

10. Boumosleh, A. (2009). Director Compensation and the Reliability of Accounting Information. The Financial Review, 44 (4) 525-539.

11. Campbell, J. (1990). Measuring the Persistence of Expected Returns. American Economic Review, 80 (2) 43-47.

12. Certo, T., Dalton, C., Dalton, D. \& Lester, R. (2008). Boards of Directors' Self Interest: Expanding for Pay in Corporate Acquisitions? Journal of Business Ethics, 77 (2) 219-230.

13. Chauvin, K. \& Shenoy, C. (2001). Stock Price Decreases Prior to Executive Stock Option Grants. Journal of Corporate Finance, 7 (1) 53-76.

14. Cheng, Q. \& Warfield, T. (2005). Equity Incentives and Earnings Management. The Accounting Review, 80 (2) $441-476$. 
15. Cordeiro, J., Veliyath, R. \& Romal, J. (2007). Moderators of the Relationship Between Director StockBased Compensation and Firm Performance. Corporate Governance: An International Review, 15 (6) 1384-1393.

16. Daily, C. \& Dalton, D. (2002). The Problem with Equity Compensation. The Journal of Business Strategy, 23 (4) 28-30.

17. Daily, C., Certo, T. \& Dalton, D. (2002). Executive Stock Option Repricing: Retention and Performance Reconsidered. California Management Review, 44 (4) 8-23.

18. Dalton, D. \& Daily, C. (2001). Director Stock Compensation: An Invitation to a Conspicuous Conflict of Interest? Business Ethics Quarterly, 11 (1) 89-108.

19. Dalton, D., Certo, T. \& Daily, C. (2003). Initial Public Offerings (IPOs) as a Web of Conflicts of Interest: An Empirical Assessment. Business Ethics Quarterly, 13 (3) 289-314.

20. Davis, G. \& Thompson, T. (1994). A Social Movement Perspective on Corporate Control. Administrative Science Quarterly, 39 (1) 141-173.

21. Dechow, P. \& Schrand, C. (2004). Earnings quality. New York: CFA Institute.

22. Dechow, P., Sloan R. \& Sweeney, A. (1995). Detecting Earnings Management. The Accounting Review, 70 (2) $193-225$.

23. DeFond, M. \& Jiambalvo, J. (1994). Debt Covenant Violations and the Manipulation of Accruals. Journal of Accounting and Economics, 17 (1-2) 145-176.

24. Elson, C. (1995). The Duty of Care, Compensation, and Stock Ownership. University of Cincinnati Law Review, 63 (2) 649-711.

25. Elson, C. (1996). Director Compensation and the Management-Captured Board-the History of a Symptom and a Cure. Southern Methodist University Law Review, 50 (1) 127-174.

26. Fama, E. (1976). Foundations of Finance, New York: Basic Books.

27. Fama, E. (1980). Agency Problems and the Theory of the Firm. Journal of Political Economy, 88 (2) $288-$ 307.

28. Fama, E. (1990). Stock Returns, Expected Returns, and Real Activity. Journal of Finance, 45 (4) 1089 1108.

29. Fama, E. \& Jensen, M. (1983a). Separation of Ownership and Control. Journal of Law and Economics, 26 (June) 301-325.

30. Fama, E. \& Jensen, M. (1983b). Agency Problems and Residual Claims. Journal of Law and Economics, 26 (June) 327- 349.

31. Fich, E. \& Shivdasani, A. (2005). The Impact of Stock-Option Compensation for Outside Directors on Firm Value. Journal of Business, 78 (6) 2229- 2254.

32. Finkelstein, S. \& Boyd, B. (1998). How Much Does the CEO Matter? The Role of Managerial Discretion on the Setting of CEO Compensation. Academy of Management Journal, 41 (2) 179-199.

33. Frankel, R., Johnson, M., \& Nelson, K. (2002). The Relation Between Auditors' Fees for Nonaudit Services and Earnings Management. The Accounting Review, 77 (Supplement) 71-105.

34. Gao, P. \& Shrieves R. (2002). Earnings Management and Executive Compensation: A Case of Overdose of Option and Underdose of Salary. Working paper, University of Tennessee.

35. Hall, S. \& Stammerjohan, W. (1997). Damage Awards and Earnings Management in the Oil Industry. The Accounting Review, 72 (1) 47-65.

36. Healy, P. (1985). The Effect of Bonus Schemes on Accounting Decisions. Journal of Accounting and Economics, 7 (1-3) 85-107.

37. Healy, P. \& Wahlen, J. (1999). A Review of the Earnings Management Literature and its Implications for Standard Setting. Accounting Horizons, 13 (4) 365-383.

38. Hermalin, B. \& Weisbach, M. (1991). The Effects of Board Composition and Director Incentives on Firm Performance. Financial Management, 20 (4)101-112.

39. Hribar, P. \& Collins, D. (2002). Errors in Estimating Accruals: Implications for Empirical Research. Journal of Accounting Research, 40 (1) 105-134.

40. Jensen, M. (1983). Organization Theory and Methodology. The Accounting Review, 58 (2) $319-339$.

41. Jensen, M. (1989). Eclipse of the Public Corporation. Harvard Business Review, 67 (5) 61-74.

42. Jensen, M. (1993). The Modern Industrial Revolution, Exit and the Failure of Internal Control Systems, Journal of Finance, 48 (3) 831-880. 
43. Jensen, M. \& Meckling, W. (1976). Theory of the Firm: Managerial Behavior, Agency Costs and Ownership Structure. Journal of Financial Economics, 3 (4) 305-360.

44. Johnson, S., La Porta, R., Lopez-de-Silanes, F. \& Shleifer, A. (2000). Tunneling. The American Economic Review, 90 (2) 22-27.

45. Jones, J. (1991). Earnings Management During Import Relief Investigations. Journal of Accounting Research, 29 (2) 193-228.

46. Key, K. (1997). Political Cost Incentives for Earnings Management in the Cable Television Industry. Journal of Accounting and Economics, 23(3) 309-338.

47. Kothari, S. (2001). Capital Markets Research in Accounting. Journal of Accounting and Economics, 31 (13) $105-231$.

48. LaCroix, K. (2009). Court Approves Outside Directors' Massive Settlement in Peregrine Systems Securities Suit', http://www.dandodiary.com/2009/07/articles/outside-director-liability/court-approvesoutside-directors-massive-settlement-in-peregrine-systems-securities-suit/

49. Lambert, R., Lanen, W. \& Larker, D. (1989). Executive Stock Option Plans and Corporate Dividend Policy. Journal of Financial and Quantitative Analysis, 24 (4) 409-425.

50. Lambert, R. \& Larcker, D. (1987). An Analysis of the Use of Accounting and Market Measures of Performance in Executive Compensation Contracts. Journal of Accounting Research, 25 (Supplement) 85125.

51. Lewellen, W., Loderer, C. \& Martin, K. (1987). Executive Compensation and Executive Incentive Problems. Journal of Accounting and Economics, 9 (3) 287-310.

52. Linn, S. \& Park, D. (2005). Outside Director Compensation and the Investment Opportunity Set. Journal of Corporate Finance, 11 (4) 680-715.

53. Maug, E. (1998). Large Shareholders as Monitors: Is There a Trade-off Between Liquidity and Control? The Journal of Finance, 53 (1) 680-715.

54. Meek, G., Rao, R. \& Skousen, C. (2007). Evidence on Factors Affecting the Relationship Between CEO Stock Option Compensation and Earnings Management. Review of Accounting and Finance, 6 (3) 304-323.

55. Menon, K. \& Williams, D. (2004). Former Audit Partners and Abnormal Accruals. The Accounting Review, 79 (4) 1095-1118.

56. Merton, R. (1973). Theory of Rational Option Pricing. The Bell Journal of Economics and Management Science, 4 (1) 141-183.

57. Murphy, K. (1999). Executive Compensation in O. Ashenfelter \& D. Cards (eds.), Handbook of labor economics: 2485-2563. North Holland: Elsevier Science.

58. National Association of Corporate Directors: (1995). Report of the nacd blue ribbon commission on director compensation: purposes, principles, and best practices. Washington, D.C: NACD.

59. Ryan, H. \& Wiggins, R. (2004). Who is in Whose Pocket? Director Compensation, Board Independence, and Barriers to Effective Monitoring. Journal of Financial Economics, 73 (3) 497-524.

60. Rumlet, R. (1987). Theory, Strategy, and Entrepreneurship, in: D. Teece (ed.), The competitive challenge, New York: Harper and Row.

61. Sloan, R. (1993). Accounting Earnings and Top Executive Compensation. Journal of Accounting and Economics, 16 (2) 55-100.

62. Smith, C. \& Watts, R. (1992). The Investment Opportunity Set and Corporate Financing, Dividend and Compensation Policies. Journal of Financial Economics, 32 (3) 263-292.

63. Sternberg, E. (2001). Just business: business ethics in action. .Oxford: Oxford University Press

64. Vafeas, N. (1999). Board Meeting Frequency and Firm Performance. Journal of Financial Economics, 53 (1) $113-142$.

65. Watts, R. \& Zimmerman, J. (1986). Positive Accounting Theory. Englewood Cliffs: Prentice Hall.

66. Williamson, O. (1984). Corporate Governance. Yale Law Journal, 93 (7) 1197-1230.

67. Yermack, D. (1996). Higher Market Valuation of Companies with a Small Board of Directors. Journal of Financial Economics, 40 (2) 185-211.

68. Yermack, D. (1997). Good Timing: CEO Stock Option Awards and Company News Announcements. The Journal of Finance, 52 (2) 449-476. 


\section{NOTES}

